\title{
Optimum plot size of planting and bio-agroeconomic revenues from arugula-carrot intercropping systems in a semi-arid region
}

\author{
FRANK W.A. DE CARVALHO ${ }^{1}$, GLAUBER H.S. NUNES ${ }^{2}$, FRANCISCO BEZERRA NETO ${ }^{2}$, AURÉLIO P. BARROS \\ JÚNIOR $^{2}$, JAILMA S.S. DE LIMA ${ }^{2}$, AHMAD S. KHAN ${ }^{3}$, JOSÉ R. DA SILVA ${ }^{4}$ and JOSERLAN N. MOREIRA ${ }^{1}$ \\ ${ }^{1}$ Instituto Federal da Paraíba, Campus Sousa, Rua Pres. Tancredo Neves, s/n, Jardim Sorrilândia, 58800-970, Sousa, PB, Brazil \\ ${ }^{2}$ Departamento de Ciências Vegetais, Universidade Federal Rural do Semi-Árido, Km 47, \\ BR 110, No 572, 59625-900 Mossoró, RN, Brazil \\ ${ }^{3}$ Departamento de Economia Agrícola, Universidade Federal do Ceará, Campus do Pici, \\ Av. Mister Hull, 2977, Bloco 847, 60451-970 Fortaleza, CE, Brazil \\ ${ }^{4}$ Empresa de Pesquisa Agropecuária do Rio Grande do Norte, Av. Francisco Mota, 572, Campus da UFERSA, \\ Bairro Pres. Costa e Silva, 59625-900 Mossoró, RN, Brazil
}

Manuscript received on June 19, 2017; accepted for publication on April 4, 2018

\begin{abstract}
The production of vegetable crops has been characterized as a highly intensive activity in the use of soil, water, inputs and labor in semi-arid regions, being practiced mostly by small family farmers as a way of subsistence, or in the small-scale commercialization of surplus production. Among the agricultural practices that have been successfully used by vegetable producers are intercrop systems that, when implemented with adequate management, present gains in productivity, nutritional, economic, and environmental value. The aim of this study was to estimate the optimal plot sizes of plantings of carrot (Daucus carota L.) intercropped with arugula (Eruca sativa L.) in bi-cultivation in three spatial arrangements, as well as to determine bio-agroeconomic revenues from associations between these vegetable crops in a semi-arid region. Estimates of optimal sizes of experimental plots in intercropping systems, provided by the methods of bootstrap resampling and of sampling intensity $(10 \%)$, were four, four and three basic units, respectively, for the spatial arrangements $2 \mathrm{R}: 2 \mathrm{C}, 3 \mathrm{R}: 3 \mathrm{C}$, and $4 \mathrm{R}$ : $4 \mathrm{C}$, between rows of arugula $(\mathrm{R})$ intercropped with carrot $(C)$, and by the Hatheway method, all spatial arrangements were of four basic units. The best bio-agroeconomic performance of carrot intercropped with arugula in bi-cultivation was obtained in the spatial arrangement 2R:2C.
\end{abstract}

Key words: Daucus carota, Eruca sativa, Plot size, Intercrop, Bio-agroeconomic index.

\section{INTRODUCTION}

The intercrop system constitutes a viable option for establishing and developing vegetable crop

Correspondence to: Aurélio Paes Barros Júnior

E-mail: aurelio.barros@ufersa.edu.br agricultural systems in semi-arid regions (Almeida et al. 2015). This practice is characterized by the planting of two or more cultures in the same area (Lima et al. 2014). These may or may not be seeded simultaneously, and their harvest times may or may not be different. The main benefit of the system 
is that, for a significant part of the cycle of both cultures, they can share the same area.

Intercrop is mainly used by small farmers, who seek to make the most of limited areas that are manually cultivated, including weeding, fertilization, pesticide application, and other cultural practices (Coelho et al. 2000), and which enable greater diversification of diet, and increased profitability per acre.

The success of research involving such vegetable crop systems depends on methods that are able to detect small, but significant, variations, thus requiring continuous improvement of the experiments, and a high level of accuracy. In order to perform experiments on intercrop with high precision, it is necessary to have a plan that adequately defines what will constitute the experimental unit, or plot, and that aims to increase experiment efficiency by reducing experimental error (Paranaíba et al. 2009a).

Previous works that have studied optimal vegetable monocrop plot sizes include those concerning pumpkin (Curcubita pepo L.: Mello et al. 2004, Hernández et al. 2006), zucchini (Curcubita pepo L.: Feijó et al. 2006), carrot (Vieira and Silva 2008), watermelon (Citrullus lanatus (Thunb.) Matsum. \& Nakai: Neppl et al. 2003), strawberry (Fragaria x ananassa Duch.: Cocco et al. 2009), and tomato (Lycopersicum esculentum upL.: Lúcio et al. 2010). There are no papers in the literature concerning the determination of plot size for intercropped vegetable crops.

Methodologies with different characteristics for determining the size of experimental plots can be found in the literature, such as a method for maximum curvature (Silva et al. 2003), the Hatheway method for maximum modified curvature (Santos et al. 2012), segmented linear models with plateau (Paranaíba et al. 2009b), bootstrap resampling (Espinosa et al. 2006), and sampling intensity (Augustynczik et al. 2013).
One of the classic ways used to study plot size is the assay, blank experiment, or uniformity. Muniz et al. (2009) considered that this is one of the best ways to study the optimal size of plots. According to Lúcio et al. (2004), a blank assay is where a given species is grown throughout the plot, submitting the entire area to the same cultural practices. Then, the area is divided into subplots, and the production of each subplot is measured separately. The yields of nearby subplots can be used to add together subplots to form parcels of different sizes and shapes. Thus, we can evaluate, and compare the variability of, soil and other factors that influence plant yield.

Various evaluation indices of intercrop systems have been used in research on crop intercrop. The land equivalent ratio is that most frequently used by researchers in this subject. Land equivalent ratio is a relatively simple concept and, when properly calculated, gives a measure of the biological efficiency and physical of the intercrop system. Indices and experimental models need to be carefully tailored to the specific goals of the experiments because certain widely-used methods can lead to erroneous evaluation of aspects of interspecific interaction and of the advantages of intercrop (Bezerra Neto et al. 2007).

In this context, the objectives of this study were to estimate the optimal plot size for a planting of carrot intercropped with arugula, in bi-cultivation, in three spatial arrangements, as well as to determine the bio-agroeconomic revenues from associations between these vegetable crops in a semi-arid region.

\section{MATERIALS AND METHODS}

\section{SITE AND CLIMATE}

Three assays of uniformity $\left(\mathrm{A}_{1}, \mathrm{~A}_{2}\right.$, and $\left.\mathrm{A}_{3}\right)$ were conducted at the Experimental Rafael Fernandes Farm in Alagoinha, $20 \mathrm{~km}$ of the city of Mossoró - RN, NE Brazil $\left(5^{\circ} 11^{\prime} \mathrm{S}, 37^{\circ} 20^{\prime} \mathrm{W}\right.$; altitude, 18 $\mathrm{m})$. The climate of the region is semi-arid and, 
according to the Köppen climate classification scheme, designated as 'BShw' - dry and very hot, with two seasons: a dry season, which usually runs from June to January; and a rainy season, from February to May (Almeida et al. 2015). The soil is classified as oxisol argisolic (EMBRAPA 2006).

\section{EXPERIMENTAL LAYOUT}

The blank assays $\left(A_{1}, A_{2}\right.$, and $\left.A_{3}\right)$ were constituted of three spatial arrangements of planting, formed by strips of two, three or four arugula (R) rows, interplanted with strips of two, three or four carrot (C) rows in an intercrop system (Figures 1-3). Assay $A_{1}$ was composed of the planting spatial arrangement $2 \mathrm{R}: 2 \mathrm{C}$, where strips formed by two rows of arugula plants were alternated with strips of two rows of carrot plants. Side and head borders were placed around the edges of the assay (Figure 1). Assay $\mathrm{A}_{2}$ was composed of the spatial arrangement 3R:3C, where strips formed of three rows of arugula plants were alternated with strips of three rows of carrot plants. The assay was flanked by side and head borders (Figure 2). Assay $\mathrm{A}_{3}$ was composed of the spatial arrangement $4 \mathrm{R}: 4 \mathrm{C}$, where strips of four rows of arugula plants were alternated with strips of four rows of carrot plants. Lateral and head borders were also placed on each side of this assay (Figure 3).

Assay $A_{1}$ was composed of 17 basic experimental units, formed by two rows of arugula and two of carrot (2R:2C). Each basic unit had a total area of $0.96 \mathrm{~m}^{2}(0.8 \mathrm{~m} \mathrm{x} 1.2 \mathrm{~m})$, with a harvest area of $0.8 \mathrm{~m}^{2}(0.8 \mathrm{mx} 1 \mathrm{~m})$, containing 80 arugula plants, spaced at $0.2 \mathrm{~m} \times 0.05$ (with two plants per hole), and 40 carrot plants, also spaced at $0.2 \mathrm{~m} \mathrm{x}$ $0.05 \mathrm{~m}$. Assay $\mathrm{A}_{2}$ was also composed of 17 basic units, in the arrangement $3 \mathrm{R}: 3 \mathrm{C}$, formed by three rows of arugula and three rows of carrot, with a total area per basic unit of $1.44 \mathrm{~m}^{2}(1.2 \times 1.2 \mathrm{~m})$, and a harvest area of $1.2 \mathrm{~m}^{2}(1.2 \mathrm{mx} 1 \mathrm{~m})$, containing 120 arugula plants, spaced at $0.2 \mathrm{~m} \times 0.05 \mathrm{~m}$ (with two plants per hole), and 60 carrot plants, spaced at 0.2 $\mathrm{m} \times 0.05 \mathrm{~m}$. Assay $\mathrm{A}_{3}$ consisted of 17 basic units in the spatial arrangement $4 \mathrm{R}: 4 \mathrm{C}$, with four rows of arugula and four of carrot, and a total area per basic unit of $1.92 \mathrm{~m}^{2}(1.6 \mathrm{~m} \times 1.2 \mathrm{~m})$, and a harvest area of $1.6 \mathrm{~m}^{2}(1.6 \mathrm{~m} \mathrm{x} 1 \mathrm{~m})$, containing 160 arugula plants, spaced at $0.2 \mathrm{~m} \times 0.05 \mathrm{~m}$ (with two plants per hole), and 80 carrot plants, spaced at $0.2 \mathrm{~m} \mathrm{x}$ $0.05 \mathrm{~m}$. Plots with single crops of arugula and carrot were planted on the sides of each assay, and had a total area of $1.44 \mathrm{~m}^{2}$, with a harvest area of $0.8 \mathrm{~m}^{2}$, with 80 arugula plants, spaced at $0.2 \mathrm{~m} \times 0.05 \mathrm{~m}$, and 40 carrot plants, spaced at $0.2 \mathrm{~m} \mathrm{x} 0.1 \mathrm{~m}$.

The plant population of each planted vegetable crop recommended by research in the region is of 500,000 plants ha $^{-1}$ for carrot (Barros Júnior et al. 2005) and 1,000,000 plants ha ${ }^{-1}$ for arugula (Freitas et al. 2009).

\section{CHARACTERISTICS EVALUATED IN THE CULTURES}

In the arugula culture, we evaluated plant height (cm), number of leaves per plant, green mass yield $\left(\mathrm{t} \mathrm{ha} \mathrm{a}^{-1}\right)$, and dry mass of shoot $\left(\mathrm{t} \mathrm{ha} \mathrm{a}^{-1}\right)$, while that in carrot culture, we evaluated plant height $(\mathrm{cm})$, number of stems per plant, shoot dry mass $\left(\mathrm{t} \mathrm{ha} \mathrm{a}^{-1}\right)$, root dry mass $\left(\mathrm{t} \mathrm{ha}^{-1}\right)$, total and commercial productivity of roots $\left(\mathrm{t} \mathrm{ha}^{-1}\right)$ and classified productivity of the roots into: a) long (length 17-25 cm, diameter less $5 \mathrm{~cm}$ ); b) medium (length $12-17 \mathrm{~cm}$, diameter greater $2.5 \mathrm{~cm}$ ); c) short (length 5-12 cm, diameter greater $1 \mathrm{~cm}$ ); and d) scrap (roots that did not fit into any of these categories) (Lana and Vieira 2000).

INDICES OF COMPETITION, AND EFFICIENCY OF INTERCROPPED SYSTEMS

The following abbreviations were used in calculating different competitive functions. $Y_{c r}$ and $Y_{r c}$ are the individual crop yields (carrot and arugula) in the intercrop, and $Y_{c c}$ and $Y_{r r}$ are their yields as sole crop. $Z_{c r}$ and $Z_{r c}$ are the proportions 


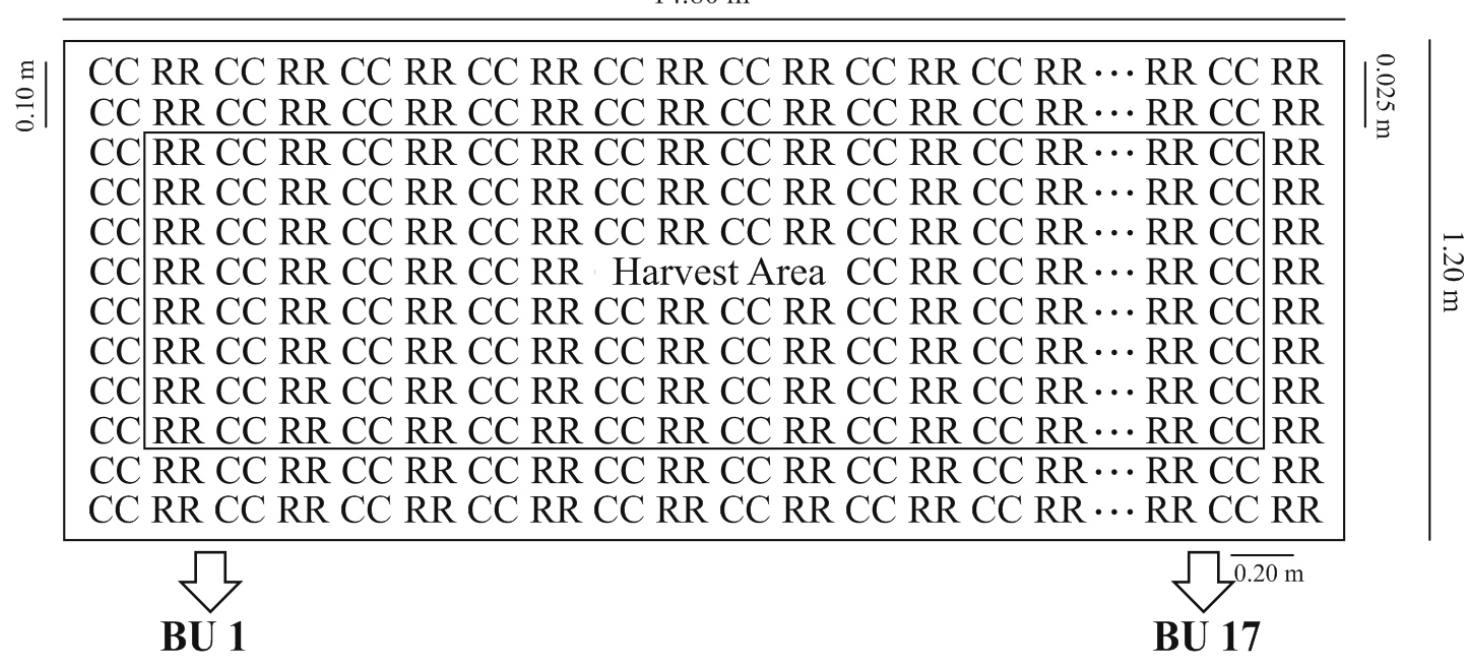

Figure 1 - Graphical representation of the blank assay $A_{1}$, formed by intercropping between arugula $(R)$ and carrot $(C)$, in the spatial arrangement 2R:2C.

$21.80 \mathrm{~m}$

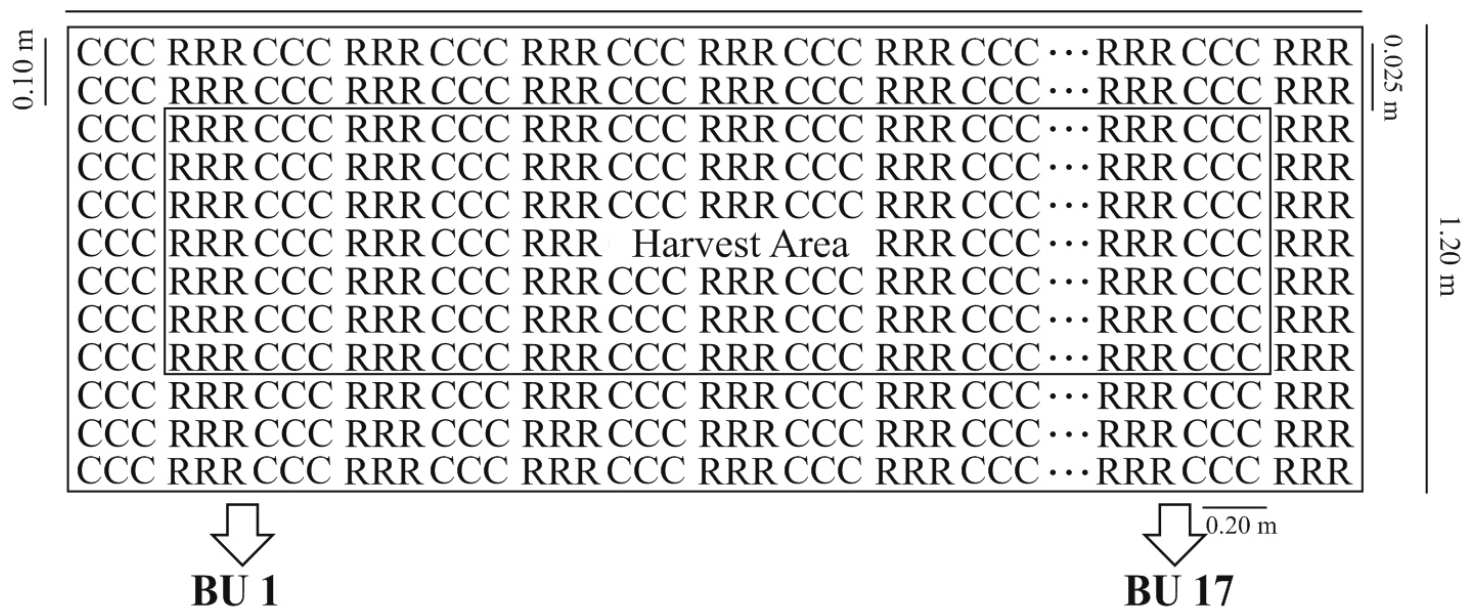

Figure 2 - Graphical representation of the blank assay $A_{2}$, formed by intercropping between arugula $(\mathrm{R})$ and carrot $(\mathrm{C})$, in the spatial arrangement 3R:3C.

of land area occupied by the intercrop, compared to the sole crops for carrot and arugula, respectively.

\section{Relative crowding coefficient of the system $(K)$}

This is a measure of the dominance of one species over another in the intercrop. When a species produces more biomass in the intercrop than in the sole crop, its $K$ is greater than one. According to Williams and McCarthy (2001), a higher value of $K$ implies a greater ability of a culture to compete; it is calculated using Equation 1 below:

$$
K=K_{c r} K_{r c}
$$

where $K_{c r}=\frac{Y_{c r}}{Y_{c c}}-Y_{c r}$ and $K_{r c}=\frac{Y_{r c}}{Y_{r r}}-Y_{c r}$, and $K_{c r}$ and $K_{r c}$ are the relative crowding coefficients for carrot and arugula, respectively. When the product of the coefficients is greater than one, there is a yield advantage in the intercrop; when $K$ is equal to one, there is no benefit in intercrop; and when $K$ is less 
$28.40 \mathrm{~m}$

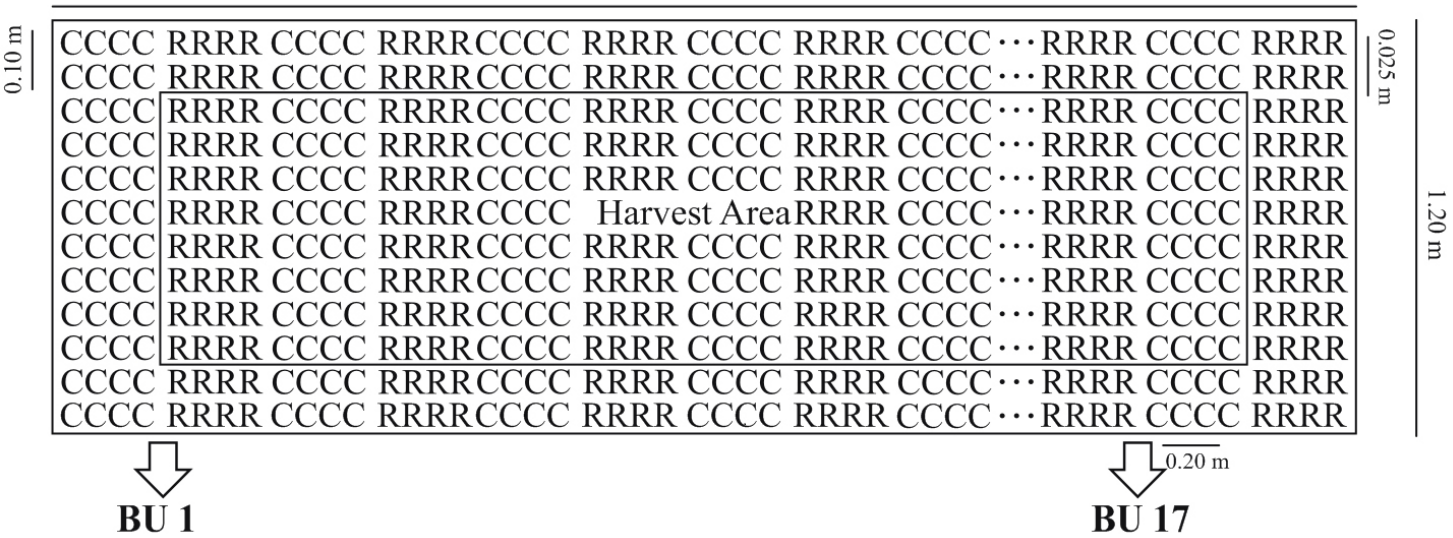

Figure 3 - Graphical representation of the blank assay $A_{3}$, formed by intercropping between arugula (R) and carrot (C), in the spatial arrangement $4 \mathrm{R}: 4 \mathrm{C}$.

than one, there is a disadvantage in the intercrop of the crops.

\section{Land equivalent ratio}

Land equivalent ratio is defined as the area of monocropped land, is required to provide the same productivity as the intercropped land, and is obtained by the following expression:

$$
L E R=L E R_{r}+L E R_{c}
$$

where $L E R$ is the land equivalent ratio, $L E R_{r}=$ $Y_{r c} / Y_{r r}$ is the partial land equivalent ratio of arugula in the intercrop, and $L E R_{c}=Y_{c r} / Y_{c c}$ is the partial land equivalent ratio of carrot in the intercrop. When the $L E R$ is greater than one, intercrop favors the development and yield of a species; when the $L E R$ is less than one, intercrop adversely affects the yield and development of the intercropped crops (Cecílio Filho et al. 2013).

\section{Aggressivity}

Aggressivity is an index for measuring the dominance of one culture over another. This index is used to indicate to what extent the increase in the relative yield of a given crop is larger than another, when they are produced under intercrop. The equations used to determine this index are:

$$
A_{c}=\left(\frac{Y_{c r}}{Y_{c c}} \times Z_{c r}\right)-\left(\frac{Y_{r c}}{Y_{r r}} \times Z_{r c}\right)
$$

and

$$
A_{r}=\left(\frac{Y_{r c}}{Y_{r r}} \times Z_{r c}\right)-\left(\frac{Y_{c r}}{Y_{c c}} \times Z_{c r}\right)
$$

where $A_{c}$ is the carrot aggressivity, and $A_{r}$ is the arugula aggressivity. If the value of $A$ is zero, both cultures are equally competitive; if $A$ has a positive sign, then it is the dominant crop component; and if it is negative, then it is the dominated culture (Bhatti et al. 2006).

\section{Competitive ratio}

The competitive ratio is another way to evaluate the competition between different cultures because it gives a better measure of the competitiveness between the cultures. The competitive ratios $C R_{C}$ and $C R_{r}$, for carrot and arugula, respectively, were obtained by the following expressions:

$$
\begin{gathered}
C R_{c}=\left[\frac{\left(\frac{Y_{c r}}{Y_{c c}}\right)}{\left(\frac{Y_{r c}}{Y_{r r}}\right)}\right] \times\left(\frac{Z_{r c}}{Z_{c r}}\right) \\
C R_{r}=\left[\frac{\left(\frac{Y_{r c}}{Y_{r r}}\right)}{\left(\frac{\left(Y_{c r}\right)}{Y_{c c}}\right)}\right] \times\left(\frac{Z_{c r}}{Z_{r c}}\right)
\end{gathered}
$$


In intercrop, the culture with the largest competitive ratio has the greater ability to use environmental resources, compared to the other component culture (Dhima et al. 2007).

\section{Actual yield loss}

The actual yield loss is an index that provides more information about competition, in relation to other indices (Banik et al. 2000). With regard to the behavior of each species in the intercropping system, it is based on yield per plant. The actual yield loss is determined by the gain or loss of yield of the intercrop, compared to the respective single culture, i.e., when considering the actual sown proportion of the component cultures, in comparison to the respective sole crop. The equation for determining the actual yield loss is:

$$
A Y L=A Y L_{r}+A Y L_{c}
$$

where $A Y L$ is the actual yield loss from intercropping; $A Y L_{r}$ is the actual yield loss of the arugula, and $A Y L_{c}$ is the actual yield loss of the carrot.

\section{Intercropping advantage}

The intercropping advantage is an indicator of economic viability, expressing the actual yield loss in monetary terms, and indicating the advantage of an intercrop system over another (Dhima et al. 2007). It is obtained by the expression:

$$
\begin{gathered}
I A=I A_{r}+I A_{c} \\
I A_{r}=A Y L_{r} \times P_{r}
\end{gathered}
$$

and

$$
I A_{c}=A Y L_{c} \times P_{c}
$$

where $I A$ is the intercropping advantage, $I A_{r}$ and $I A_{c}$ are the intercropping advantages for arugula and carrot, respectively, and $P_{r}$ and $P_{c}$ are the prices for arugula and carrot, respectively, at $\mathrm{R} \$ \mathrm{~kg}^{-1}$.

\section{ECONOMIC INDICATORS}

\section{Production cost}

The costs were calculated and analyzed at the end of the production process, in January 2011, proceeding to the cost analysis ex post. The cost method used in this study corresponds to the total expenditure (total cost) per hectare of cultivated area, which covers the services provided by stable capital, i.e., the contribution of working capital and the value of alternative costs (also called cost opportunity). Similarly, revenue refers to the production value of one hectare.

\section{Costs associated with stable capital}

Depreciation

Depreciation is defined as a non-monetary fixed cost that reflects the loss of value of producted goods, as a function of their age, use and obsolescence. The method used to determine the depreciation value was linear (method of fixed quotas), which determines the annual value of depreciation from the lifetime of the durable goods, from its initial value to scrap value. The latter was not considered, since the considered capital goods show any residual value.

Opportunity cost and alternative cost

For the stable capital items (buildings, machinery, equipment, etc.), the opportunity cost is the annual interest that reflects the alternative use of the capital. According to Silva et al. (2015), the interest rate chosen for the calculation of the alternative cost must equal the rate of return of the best alternative application. As it was impossible to determine this value, we decided to adopt the rate of $6 \%$ per year, equivalent to the gain in savings. As capital goods depreciate over time, the interest focuses on half of the current value of each of the goods. Regarding the opportunity cost of land, we considered the lease 
of a hectare in the region as the equivalent of the alternative cost of the land used in the search.

\section{Fixed manual labor}

It is destined to the management of the productive activities, corresponding to the payment of a minimum wage per month during the production cycle.

Cost associated with working capital

\section{Purchase cost}

The purchase cost is obtained by multiplying the price of the variable input used (seeds, fertilizer, pesticides, potential labor, etc.) by the amount of the respective input used.

\section{Conservation and maintenance}

These variable costs are for the maintenance and upkeep of facilities, machinery, and equipment directly related to production. The value set for these expenses was $1 \%$ per year of the construction cost value; in the case of the pump and irrigation system, the percentage was $7 \%$ per annum.

\section{Deadline}

The period between the application of resources and the response of the same as a product refers to the duration of the production cycle of activity (harvest). In this case, a single production cycle was considered to be 90 days.

\section{Economic outcome measures}

Analysis of the income through indicators of economic output was used to assess the efficiency of the administrator and the workforce. The economic analysis also enabled us to verify whether, and how, the resources allocated to a production activity were being paid, and allowed us also to check performance in relation to the profitability of the activity in question, compared to alternatives for the use of the time and capital. Thus, the indicators analyzed were:

Gross income. This corresponds to the value of the obtained output per hectare in the intercrop system, and the price paid to producers in the region. For the carrot and arugula, the values paid were $\mathrm{R} \$ 1.89 \mathrm{~kg}^{-1}$ and $\mathrm{R} \$ 4.60 \mathrm{~kg}^{-1}$, respectively.

Net income. The difference between gross income per hectare and the total cost involved in achieving it.

Return rate. Defined as the relationship between gross income and total cost, corresponding to how much reals are obtained in return for each real invested in the evaluated intercrop system.

Profit margin. The ratio between net income and gross income, expressed as a percentage.

Modified monetary advantage. An indicator of the economic advantage of the intercrop, obtained by:

$$
M M A=\frac{(\text { Intercroppingvalue }) \times(L E R-1)}{L E R}
$$

\section{STATISTICAL ANALYSIS}

The optimum plot size for each assay was estimated by five methods, using the land equivalent ratio, which is the most used in assessing intercrop systems, as outlined below.

\section{Bootstrap resampling}

Each basic unit was considered as sample unit. The process was based on the resampled bootstrapping non-parametric technique (Efron and Tibshirani 1993). It was performed on 1,000 resamplings with replacement, generating 1,000 new datasets for each value of $n$ (number of basic units), where $n=$ $1,2, \ldots, 17$ basic units. To determine the size of the plot, an adaptation of the methodology presented by Xie and Mosjidis (1997) was performed. A confidence interval was constructed for the variance of the average in the original dataset (20 plants), according to the methodology presented by Barbin (1993), with the confidence level $\beta=$ 
$95 \%$. The sample size via bootstrap resampling was determined from counting the number of average variance estimates, which are positioned within the confidence intervals constructed with the population values (values obtained with itn $=17$ basic units).

\section{Segmented linear models with plateau}

The theory of segmented linear models with plateau was applied in the context of the plot dimensions. For this, we adopted the model:

$$
C V_{(X)}= \begin{cases}\beta_{0}+\beta_{1} X+\varepsilon & \text { se } X \leq X_{0} \\ C V P+\varepsilon & \text { se } X>X_{0}\end{cases}
$$

$C V_{(X)}$ is the coefficient of variation of each established sample size; $\mathrm{X}$ is the size of the plot; $X_{0}$ is the optimum plot size at which the linear model turns into a plateau, in relation to the abscissa; CVP is the coefficient of variation at the point corresponding to the plateau (junction of the linear segment and plateau); $\beta_{0}$ and $\beta_{1}$ are the intercept and slope, respectively, of the linear segment; and $\varepsilon_{x}$ is the error associated with the $C V_{(X)}$, supposedly normal and independently distributed with mean 0 and variance $\sigma^{2}$ constant. To achieve continuity, the two segments (linear and plateau) must meet at the point $X_{0}$. Thus, $\beta_{0}+\beta_{1} X_{0}=C V P$ :

$$
X_{0}=\frac{\left(C V P-\beta_{0}\right)}{\beta_{1}}
$$

To obtain fit through least squares it is necessary to obtain the partial derivatives with respect to the parameters $\left(\beta_{0}, \beta_{1}, C V P\right)$ model. The parameter $X_{0}$ is a function of the parameters $\beta_{0}, \beta_{1}, C V P$. Thus, the partial derivatives are given by:

$$
\begin{gathered}
\frac{\partial C V_{(X)}}{\partial \beta_{0}}=Z_{(X)} \\
\frac{\partial C V_{(X)}}{\partial \beta_{1}}=X Z_{X} \\
\frac{\partial C V_{(X)}}{\partial C V P}=1-Z_{X}
\end{gathered}
$$

The partial derivatives, at first, appear not to be functions of the parameters $\beta_{0}, \beta_{1}, C V P$, which will classify the model as linear in the parameters; however, we found that these functions are $Z_{X}$, which depends on $X_{0}$, which in turn is a function of the parameters $\beta_{0}, \beta_{1}$ and $C V P$. Thus, we used the Gauss-Newton method for the adjustment of this model. For this, we utilized the method of least squares for non-linear models of Gauss-Newton. The value $X_{0}$ was regarded as the optimum plot size, to stabilize the $C V_{(X)}$ to a minimum level of CVP.

\section{Maximum modified curvation method}

The method of modified maximum curvature (Silva et al. 2003) consists of representing the relationship between the experimental variation coefficient (CV\%) and the size of the plot, using a nonlinear regression equation in which $\boldsymbol{y}$ represents the coefficient of variation, and $\boldsymbol{x}$ corresponds to the size of the plot in basic units. In this study, we used the function $\mathrm{CV}=\mathrm{a} \mathrm{X}^{\mathrm{b}}$, where the value of the abscissa at the point of maximum curvature is given by the following expression, adapted by Nunes et al. (2006):

$$
X_{c}=\frac{\left(2 b^{\prime}+2\left(a^{\prime}\right)^{2}\left(b^{\prime}\right)\right)}{\left(b^{\prime}\right)^{3}}
$$

where $X_{c}$ is the value of the abscissa, corresponding to the point of maximum curvature (sample size); and estimates were obtained from the regression model $Y=a^{\prime} / X^{b^{\prime}}$. In this method, 1,000 samples were generated by resampling for sample sizes of basic units from 1 to 17 , as described in item 2.2.

\section{Sampling intensity method}

To determine the amount of plots of a certain size, the intensity method of sampling uses the number of basic units of each spatial arrangement. The 
minimum sample size is achieved by the following expression (Cochran 1977):

$$
n_{0}=\frac{t_{\alpha \cdot}^{2} \cdot(C V)^{2}}{(L E)^{2}}
$$

where $n_{0}$ is the minimum sample size (minimum number of spatial arrangements); tabulated $t$ value with $\mathrm{v}$ degrees of freedom and a significance level $\alpha ; C V \%$ is the coefficient of variation as a percentage; $L E$ is the admitted sampling error limit (usually 10\%). Given a finite population, it is necessary to apply a correction to populations with these characteristics, so that you can get the final sample size $(n)$, given by the expression below (Cochran 1977):

$$
n=\frac{n_{0}}{1+\frac{n_{0}}{N}}
$$

The sampling intensity has as initial characteristic to estimate the coefficient of variation of the variance analysis of the plot, where the number of units $\left(n_{0}\right)$ that originated is arbitrary, and obtaining the value of $n$ with $v_{0}=n_{0}-1$ degrees of freedom, we needed to thereby adjust the calculated intensity. The adjustment was made from the first approximation in calculating the sampling intensity $\left(n_{1}\right)$, by taking the new value of $n$ for $v_{1}=n_{1}-$ 1 degrees of freedom to get the second approach $\left(n_{2}\right)$; then we used the new value of $n$ for $v_{2}=$ $n_{2}-1$ degrees of freedom to determine the third approach $\left(n_{3}\right)$. The process is repeated until the value of the sampling intensity becomes constant (Nunes et al. 2006).

\section{Hathaway method}

The method Hathaway (1961) is based on the following equation:

$$
X^{b}=\frac{2\left(t_{1}+t_{2}\right)^{2} C V^{2}}{r d^{2}}
$$

where $\mathrm{X}$ is the size of the plot in basic units; $\mathrm{b}$ is the coefficient, or soil heterogeneity index; $t_{1}$ is the critical value of the Student's t distribution, with probability $\alpha_{1} ; t_{2}$ is the critical value of the Student's $t$ distribution, with probability $\alpha_{2}=2$ (1 $\mathrm{P})$, where $\mathrm{P}$ is the probability selected to obtain a significant result; $\mathrm{CV}$ is the coefficient of variation as a percentage, selected from earlier tests, or arbitrary; $r$ is the number of repetitions; $d$ is the difference to be detected, measured as a percentage of the average.

In estimating the size of the plot by this method, we adopted the precision level $\alpha_{1}=5 \%$ and $\mathrm{P}=$ $0.80 \%$, for various combinations of the number of replications $(3,4$, and 5$)$, number of treatments $(5$, 10 , and 15$)$, coefficients of variation $(5,10,15,20$, and $25 \%$ ) and detected differences between means of 10,15 , and $20 \%$.

Considering the number of replications 2, 3, 4 , and 5, with the heterogeneity index (b), and the coefficient of variation of each blank assay, we determined the detected significant difference for plot sizes $(\mathrm{X})$ ranging from 1 to $30 \mathrm{~m}^{2}$, as the following expression:

$$
d^{2}=\frac{2\left(t_{1}+t_{2}\right)^{2} C V^{2}}{r X^{b}}
$$

The agronomic characteristics of each component culture of the intercrop system, as well as the indices of competition, and efficiency and economic indicators, were analyzed, using the following mathematical model:

$$
y_{i j}=\mu+\tau_{i}+\varepsilon_{i j}
$$

where $i=1,2$, and $3 ; j=1,2,3, \ldots, 17 ; y_{i j}$ $=$ observed value of basic unit that received the spatial arrangement ' $\mathrm{i}$ ' in the repetition ' $\mathrm{j}$ '; $\mu=$ general average; $\tau_{i}=$ effect of spatial arrangement 'i' applied to the basic unit; $\varepsilon_{i j}=$ effect of factors not controlled in the basic unit. The tested spatial arrangements were compared using the Tukey test at $5 \%$ probability. A joint analysis was performed for the arugula characteristics as a function of the 
studied spatial arrangements and their cultivations in the intercrop, as the following statistical model:

$$
y_{i j k}=\mu+\tau_{i}+\rho_{k}+\tau \rho_{(i k)}+\varepsilon_{i j k}
$$

where $i=1,2,3 ; j=1,2,3, \ldots, 17 ; k=1,2$; $y_{i j k}=$ observed value in the basic unit that received the $\mathrm{i}$-th spatial arrangement in the $\mathrm{j}$-th repetition of the k-th arugula cultivation; $\mu=$ general average; $\tau_{i}=$ effect of the $\mathrm{i}$-th spatial arrangement applied to the basic unit; $\rho_{k}=$ effect of the k-th arugula cultivation in the basic unit; $\tau \rho_{(i k)}=$ eEffect of the interaction of the i-th spatial arrangement with the $\mathrm{k}$-th arugula cultivation in the basic unit; $\bar{\varepsilon}_{i j k}=$ mean random error associated with observation $y_{i j k}$, such that $\varepsilon_{i j k} \tilde{\mathrm{N}}\left(0, \sigma^{2}\right)$.

\section{RESULTS}

\section{OPTIMAL SIZE OF PLOTS}

The number of basic units necessary to optimize the size of the experimental plot of carrot intercropped with arugula in bi-cultivation was four basic units for the spatial arrangements $2 \mathrm{R}: 2 \mathrm{C}$ and $3 \mathrm{R}: 3 \mathrm{C}$, and three basic units for the spatial arrangement 4R:4C, determined by the bootstrap resampling method (Table I). Using the segmented model with plateau, the quantities in basic units were seven for the spatial arrangements $2 \mathrm{R}: 2 \mathrm{C}$ and $3 \mathrm{R}: 3 \mathrm{C}$, and six for the spatial arrangement 4R:4C (Table I). Using the model modified maximum curvature, these values were one basic unit for all spatial arrangements (Table I).

The number of basic units obtained with the sampling intensity method (when it established a maximum error of 5\%) was nine for spatial arrangements $2 \mathrm{R}: 2 \mathrm{C}$ and $3 \mathrm{R}: 3 \mathrm{C}$, and seven for the spatial arrangement 4R:4C (Table I). When the error was $10 \%$, the amount of basic units was approximately four for the spatial arrangements $2 \mathrm{R}: 2 \mathrm{C}$ and $3 \mathrm{R}: 3 \mathrm{C}$, and approximately three for the spatial arrangement 4R:4C (Table I).
The Hatheway method has the characteristic of providing not one estimate of the optimal size of an experimental plot, but several optional sizes, and so we have the opportunity to choose the one that is most convenient (Henriques Neto et al. 2004). Settling various combinations of values of the $\mathrm{CV}$ equal to $10 \%, 20 \%$, and $30 \%$; the number of repetitions (r) equal to $2,3,4$, and 5; of treatment (t) equal to 10,15, and 20; and the mean percentage difference to be detected (d), equal to $5 \%, 10 \%$, $15 \%, 20 \%, 25 \%$, and $30 \%$, appropriate tables for determining the optimal plot size were obtained.

ARUGULA AND CARROT - PRODUCTION AND ITS COMPONENTS

There was significant interaction between the types of spatial arrangements of the arugula and carrot intercropped, and the arugula crops in the height of the arugula plants (Table II). Partitioning the interaction, types of spatial arrangements within each arugula crop, we observed significant differences in the heights of the arugula plants in the second crop, with arrangement $2 \mathrm{R}: 2 \mathrm{C}$ standing out from the rest. There was no significant difference in the heights of arugula plants between the spatial arrangements in the first crop. Moreover, unfolding the arugula crops within each spatial arrangement, we observed that the heights of arugula in the first crop stood out from the second crop only in the spatial arrangement 3R:3C (Table II).

We did not find significant interaction between the types of spatial arrangements of intercropped arugula and carrot and the arugula crops in the number of leaves per plant, in the yield of green mass, and shoot dry mass of the arugula; however, the arrangement $2 \mathrm{R}: 2 \mathrm{C}$ stood out from the others, and the first arugula crop stood out from the second crop in these evaluated characteristics (Table III). Considering the accumulated yields of green mass and shoot dry mass from the two arugula crops, we observed a significant difference between the spatial arrangements of the arugula, 
TABLE I

*Number of basic units needed to optimize results, as a function of the spatial arrangement of carrot intercropped with arugula in a bi-cultivation, using the methods of bootstrap resampling (BRs), segmented model with plateau (SMP), modified maximum curvature (MMC), and sampling intensity (SI).

\begin{tabular}{cccccc}
\hline \multirow{2}{*}{ Spatial Arrangment } & \multirow{2}{*}{ BRs } & \multirow{2}{*}{ SMP } & \multirow{2}{*}{ MMC $\left(\mathbf{X}_{\mathbf{c}}\right)$} & \multicolumn{2}{c}{ SI } \\
\cline { 5 - 7 } & & & & $\mathbf{5}(\%)$ & $\mathbf{1 0}(\%)$ \\
\hline 2R:2C & 4 & 7.38 & 0.18 & 8.6 & 3.5 \\
3R:3C & 4 & 6.54 & 0.12 & 8.8 & 3.6 \\
4R:4C & 3 & 6.36 & 0.10 & 6.7 & 2.4 \\
\hline
\end{tabular}

TABLE II

* Mean values of plant height (PH), number of leaves per plant (NL), green mass yield (GMY), and shoot dry mass (SDM) of arugula, as a function of the spatial arrangements of intercropped arugula and carrot, and two successive crops of arugula.

\begin{tabular}{|c|c|c|c|c|c|}
\hline \multirow{2}{*}{ Spatial Arrangement } & \multicolumn{2}{|c|}{ PH (cm) } & \multirow{2}{*}{ NL } & \multirow{2}{*}{ GMY $\left(\mathrm{t} \mathrm{ha}^{-1}\right)$} & \multirow{2}{*}{$\operatorname{SDM}\left(\mathrm{t} \mathrm{ha}^{-1}\right)$} \\
\hline & First crop & Second crop & & & \\
\hline $2 \mathrm{R}: 2 \mathrm{C}$ & $13.92 \mathrm{aA}$ & $14.71 \mathrm{aA}^{*}$ & $7.129 \mathrm{a}$ & $4.944 \mathrm{a}$ & $0.818 \mathrm{a}$ \\
\hline $3 \mathrm{R}: 3 \mathrm{C}$ & $13.60 \mathrm{aA}$ & $11.41 \mathrm{bB}$ & $6.363 \mathrm{~b}$ & $3.448 \mathrm{~b}$ & $0.697 \mathrm{~b}$ \\
\hline 4R:4C & $12.86 \mathrm{aA}$ & $11.62 \mathrm{bA}$ & $6.394 \mathrm{~b}$ & $3.009 \mathrm{~b}$ & $0.695 \mathrm{~b}$ \\
\hline \multicolumn{6}{|c|}{ Arugula crops } \\
\hline First crop & & & $6.902 \mathrm{a}$ & $4.601 \mathrm{a}$ & $0.937 \mathrm{a}$ \\
\hline Second crop & & & $6.356 \mathrm{~b}$ & $3.000 \mathrm{~b}$ & $0.536 \mathrm{~b}$ \\
\hline $\mathrm{CV}(\%)$ & \multicolumn{2}{|c|}{14.63} & 12.75 & 28.77 & 22.70 \\
\hline
\end{tabular}

* Means followed by the same small letter in the column and capital letter in the row do not differ by Tukey test at 5\% probability.

with arrangement $2 \mathrm{R}: 2 \mathrm{C}$ standing out from the others (Table III).

Among the indices of competition, significant differences were observed between the spatial arrangements in the relative crowding coefficient of the arugula (Ksubscriptr), in the aggressivity of carrot and arugula, and in the competitive ratios for arugula and carrot, with the spatial arrangement 2R:2C excelling from the others in the relative crowding coefficient of the arugula and in the competitive ratio of arugula (Table IV). The spatial arrangements $2 \mathrm{R}: 2 \mathrm{C}$ and $3 \mathrm{R}: 3 \mathrm{C}$ stood out from the $4 \mathrm{R}: 4 \mathrm{C}$ in the aggressivity of the crops, and arrangements $3 \mathrm{R}: 3 \mathrm{C}$ and $4 \mathrm{R}: 4 \mathrm{C}$ excelled from the $2 \mathrm{R}: 2 \mathrm{C}$ in the competitive ratio of carrot. We did not observe any significant difference between the spatial arrangements in the relative crowding coefficients of the carrot and system, and in the competitive ratio of the system (Table IV).

Significant differences between the spatial arrangements of planting in all agronomic indices of arugula and carrot were observed (Table $\mathrm{V})$, with the arrangement $2 \mathrm{R}: 2 \mathrm{C}$ standing out from the others in the land equivalent ratios of arugula and the system, in actual yield losses of arugula and the system, and in the intercropping 
TABLE III

* Mean values of green mass yield (GMY) and shoot dry mass (SDM) of arugula from two successive crops, as a function of spatial arrangements of intercropped arugula and carrot.

\begin{tabular}{|c|c|c|}
\hline Spatial Arrangement & GMY (t ha' $\left.{ }^{-1}\right)$ & $\operatorname{SDM}\left(\mathrm{t} \mathrm{ha}^{-1}\right)$ \\
\hline $2 \mathrm{R}: 2 \mathrm{C}$ & $9.888 \mathrm{a} *$ & $1.636 \mathrm{a}$ \\
\hline $3 \mathrm{R}: 3 \mathrm{C}$ & $6.895 \mathrm{~b}$ & $1.395 \mathrm{~b}$ \\
\hline $4 \mathrm{R}: 4 \mathrm{C}$ & $6.018 \mathrm{~b}$ & $1.390 \mathrm{~b}$ \\
\hline $\mathrm{CV}(\%)$ & 23.41 & 16.60 \\
\hline
\end{tabular}

* Means followed by the same small letter in the column do not differ by Tukey test at $5 \%$ probability.

TABLE IV

Mean values of relative crowding coefficients of arugula $\left(K_{r}\right)$, carrot $\left(K_{c}\right)$, and the system $(K)$, aggressivity of arugula $\left(A_{r}\right)$, carrot $\left(A_{c}\right)$, competitive ratios of arugula $\left(C R_{r}\right)$, carrot $\left(C R_{c}\right)$, and the system $(C R)$ in different spatial arrangements of intercropped arugula and carrot.

\begin{tabular}{ccccccccc}
\hline Spatial Arrangement & $\mathbf{K}_{\mathbf{r}}$ & $\mathbf{K}_{\mathbf{c}}$ & $\mathbf{K}$ & $\mathbf{A}_{\mathbf{r}}$ & $\mathbf{A}_{\mathbf{c}}$ & $\mathbf{C R}_{\mathbf{r}}$ & $\mathbf{C R}_{\mathbf{c}}$ & $\mathbf{C R}$ \\
\hline 2R:2C & $0.60 \mathrm{a} *$ & $26.00 \mathrm{a}$ & $15.60 \mathrm{a}$ & $-2.21 \mathrm{a}$ & $2.21 \mathrm{a}$ & $1.09 \mathrm{a}$ & $0.96 \mathrm{~b}$ & $2.05 \mathrm{a}$ \\
3R:3C & $0.31 \mathrm{~b}$ & $17.39 \mathrm{a}$ & $5.39 \mathrm{a}$ & $-2.19 \mathrm{a}$ & $2.19 \mathrm{a}$ & $0.82 \mathrm{~b}$ & $1.30 \mathrm{a}$ & $2.12 \mathrm{a}$ \\
4R:4C & $0.23 \mathrm{~b}$ & $11.91 \mathrm{a}$ & $2.74 \mathrm{a}$ & $-1.89 \mathrm{~b}$ & $1.89 \mathrm{~b}$ & $0.83 \mathrm{~b}$ & $1.25 \mathrm{a}$ & $2.08 \mathrm{a}$ \\
\hline $\mathrm{CV}(\%)$ & 59.59 & 261.78 & 482.02 & -16.68 & 16.68 & 22.79 & 14.71 & 5.06 \\
\hline
\end{tabular}

*Means followed by the same small letter in the column do not differ by Tukey test at $5 \%$ probability.

advantage of arugula and the system. The spatial arrangements $2 \mathrm{R}: 2 \mathrm{C}$ and 3R:3C also excelled over the arrangement $4 \mathrm{R}: 4 \mathrm{C}$ in the land equivalent ratio of carrot, actual yield loss of carrot, and in the intercropping advantage of carrot (Table V).

\section{ECONOMIC INDICATORS}

With respect to economic indices, significant differences were observed in gross income, net income, modified monetary advantage, rate of return, and profit margin, respectively, between the spatial arrangements, with the arrangement 2R:2C standing out from the others (Table VI). On the other hand, comparing arrangement 3R:3C with arrangement 4R:4C, we also noted that the former stood out from the latter in all evaluated characteristics. Despite significant differences in these economic indices among the different spatial arrangements, we observed that, in general, there is economic efficiency in the use of intercropped systems based on all of the spatial arrangements studied.

\section{DISCUSSION}

OPTIMAL SIZE OF PLOT

\section{Bootstrap}

Herein, 1,000 samples were generated, with values of the land equivalent ratio determined from the productivities (in $\mathrm{t} \mathrm{ha}^{-1}$ ) of intercropped arugula and carrot. Thus, in each of the basic units $(1,2$, $\ldots, 17)$ of each of the spatial arrangements $(2 \mathrm{R}: 2 \mathrm{C}$, 3R:3C and 4R:4C) an averaged variance estimation was generated; i.e., 1,000 estimates of the mean 
TABLE V

Mean values of the land equivalent ratios of arugula $\left(\mathrm{LER}_{\mathrm{r}}\right)$, carrot $\left(\mathrm{LER}_{\mathrm{c}}\right)$, and the system (LER), actual yield losses of arugula $\left(A Y L_{r}\right)$, carrot $\left(A Y L_{c}\right)$, and the system $(A Y L)$, and intercropping advantages of arugula $\left(I A_{r}\right)$, carrot (IA $)$, and the system (IA) in different spatial arrangements of intercropped arugula and carrot.

\begin{tabular}{cccccccccc}
\hline Spatial Arrangement & LER $_{\mathbf{r}}$ & $\mathbf{L E R}_{\mathbf{c}}$ & $\mathbf{L E R}$ & $\mathbf{A Y L}_{\mathbf{r}}$ & $\mathbf{A Y L}_{\mathbf{c}}$ & $\mathbf{A Y L}$ & $\mathbf{I A}_{\mathbf{r}}$ & $\mathbf{I A}_{\mathbf{c}}$ & $\mathbf{I A}$ \\
\hline 2R:2C & $0.52 \mathrm{a}^{*}$ & $0.99 \mathrm{a}$ & $1.51 \mathrm{a}$ & $0.58 \mathrm{a}$ & $0.48 \mathrm{a}$ & $1.06 \mathrm{a}$ & $2.67 \mathrm{a}$ & $0.89 \mathrm{a}$ & $3.56 \mathrm{a}$ \\
3R:3C & $0.36 \mathrm{~b}$ & $0.91 \mathrm{a}$ & $1.27 \mathrm{~b}$ & $0.10 \mathrm{~b}$ & $0.35 \mathrm{a}$ & $0.45 \mathrm{~b}$ & $0.47 \mathrm{~b}$ & $0.66 \mathrm{a}$ & $1.13 \mathrm{~b}$ \\
4R:4C & $0.32 \mathrm{~b}$ & $0.78 \mathrm{~b}$ & $1.10 \mathrm{c}$ & $-0.04 \mathrm{~b}$ & $0.16 \mathrm{~b}$ & $0.12 \mathrm{c}$ & $-0.17 \mathrm{~b}$ & $0.31 \mathrm{~b}$ & $0.14 \mathrm{~b}$ \\
\hline CV(\%) & 23.43 & 13.21 & 12.94 & 132.15 & 53.48 & 67.78 & 53.49 & 53.49 & 88.50 \\
\hline
\end{tabular}

* Means followed by the same small letter in the column do not differ by Tukey test at $5 \%$ probability.

TABLE VI

Mean values of gross income (GI), net income (NI), modified monetary advantage (MMA), return rate $(\mathrm{RR})$, and profitability index (PM) in different spatial arrangements of intercropped arugula and carrot.

\begin{tabular}{cccccc}
\hline Spatial Arrangement & GI & NI & MMA & RR & PM \\
\hline 2R:2C & $105,124.35 \mathrm{a}^{*}$ & $86,663.84 \mathrm{a}$ & $29,414.67 \mathrm{a}$ & $4.51 \mathrm{a}$ & $82.15 \mathrm{a}$ \\
3R:3C & $86,250.17 \mathrm{~b}$ & $67,789.67 \mathrm{~b}$ & $14,623.79 \mathrm{~b}$ & $4.02 \mathrm{~b}$ & $78.16 \mathrm{~b}$ \\
4R:4C & $74,759.65 \mathrm{c}$ & $56,299.14 \mathrm{c}$ & $5,165.75 \mathrm{c}$ & $3.57 \mathrm{c}$ & $75.03 \mathrm{c}$ \\
\hline $\mathrm{CV}(\%)$ & 13.59 & 17.16 & 60.59 & 10.64 & 3.45 \\
\hline
\end{tabular}

*Means followed by the same small letter in the column do not differ by Tukey test at $5 \%$ probability.

variance were generated. We observed a reduction of the mean variance with an increase in sample size, as reported by Gomez and Gomez (1984). As a consequence, we observed a smaller number of estimates of the mean variance outside the confidence interval, according to Barbin's (1993) methodology. The average of the 1,000 estimates of the mean variance in each plot size tended to be close to the parametric value of the total of 17 basic units. This fact has been observed in sugarcane (Saccharum officinarum up L.: Leite 2007) and melon (Cucumis melo L.: Nunes et al. 2006, Moura 2008) in studies involving bootstrapping.

In the present study, it was possible to determine the plot size of four units for the $2 \mathrm{R}: 2 \mathrm{C}$ and 3R:3C arrangements, and three units for the 4R:4C arrangement to estimate the land equivalent ratio for the intercropped carrot with arugula in bi-cultivation. From the results obtained in this research, we can confirm the usefulness of the bootstrap method to define plot size, adding another utility for this technique. The method performs well and allows a high number of iterations. Studies using bootstrapping to determine plot size, or sample size, are still in the early days (Nunes et al. 2006, Silva 2009, Cargnelutti Filho et al. 2012, Toebe et al. 2014); the relevant aspect of our work is that we pioneer the application for intercropped cultures.

\section{Segmented model with plateau}

The use of segmented models with plateau is relatively recent for plot size determination studies. A few studies have considered this method, but only 
in monocultures (Paranaíba et al. 2009a, Peixoto et al. 2011, Sousa et al. 2015); however, there are no studies on intercropped crops.

In our study, the number of basic units for the plot size of carrot intercropped with arugula in bi-cultivation, in each of the special arrangements studied, using the segmented model with plateau, were, respectively, seven basic units for the spatial arrangements $2 \mathrm{R}: 2 \mathrm{C}$ and $3 \mathrm{R}: 3 \mathrm{C}$, and six basic units for the $4 \mathrm{R}: 4 \mathrm{C}$ arrangement. These values are higher than those obtained from the bootstrap method.

In the only report we could find in the literature, comparing the bootstrap resampling method and the segmented model with plateau, Moura (2008) observed a small superiority of bootstrapping for three characters of melon evaluated in monocultured yellow melon hybrids. A possible explanation for this relates to the intrinsic mathematical characteristics of the equations that make up the method, since the point of junction between the linear method and the plateau is usually at coordinates of greater value; however, further studies are needed to safely compare the performance of the two methods in determining plot size.

\section{Maximum modified curvation method and sampling intensity method}

The sample size values obtained by the modified maximum curvature method were small, with a basic unit in each spatial arrangement studied (Table I). It is true that the plot sizes estimated by the said method are not consistent with the sensible sizes of experimental plots. Reduced or underestimated values of plot size determined by the modified maximum curvature method, have been observed on several occasions (Henriques Neto et al. 2009, Lima et al. 2007, Moura 2008).

The modified maximum curvature method (Meier and Lessman 1971) is the one most used in studies to determine sample size or plot size.
This method can be used to compare one or more methods (Bakker 1988). The property of the method consists of determining the point of maximum curvature, algebraically, considering the maximum curvature and the vertex of the curve, but not the point of stabilization of the values of the experimental coefficient of variation.

Thus, an increase in the number of plants in the plot promotes significant gain in the experimental precision, since the vertex of the curve of the coefficient of experimental variation tends to occur always in the region of the small plots. Thus, this method has, in its conception, an inconvenience, and tends to underestimate the optimal number of plants per plot (Silva et al. 2003). According to Chaves (1985), the values found by the modified maximum curvature method should be interpreted as the minimum limit of plot size, and not as optimal size.

The plot size estimated in this work by the modified maximum curvature method was smaller than that from the linear model segmented with plateau, a fact observed in several other works (Moura 2008, Paranaíba et al. 2009b, Brito et al. 2012). According to Brito et al. (2012), the explanation lies in the fact that the abscissa value at the point of maximum curvature tends to occur in the region of smaller parcel sizes.

In other studies, however, the opposite result was observed, that is, the segmented linear model with plateau presented smaller sizes of plot than those obtained by the modified maximum curvature method (Cargnelutti Filho et al. 2011, Sousa et al. 2015). This discrepancy is probably due to the occurrence of a 'false' plateau. According to Peixoto et al. (2011), a possible false plateau can be obtained when using segmented models, since there is not always sufficient amplitude in the simulated plot sizes to reach a plateau response, i.e., when the domain (different sizes of simulated plots) is limited or small, something that did not occur in this work. 
The size of the plot by the modified maximum curvature method, of course, was also smaller than that obtained by the bootstrap method, as observed by Moura (2008) in melon.

Regarding the method of sampling intensity, considering $5 \%$ error, we verified that the plot size estimates were high, when compared to the estimates obtained by other methodologies. This result was expected, and is related to the modeling of the method that produces elevation in the estimate, as the level of error is reduced. Moura (2008), in melon, also found similar results, although the estimates from the intensity method of sampling, considering 5\% error, have magnitudes that would make trials with the melon culture unfeasible.

On the other hand, considering an error of $10 \%$, the estimates were very similar to the bootstrap method, and lower than the linear model segmented with plateau method. This result differs, in part, from that observed by Moura (2008), since the author reported lower values when compared to the bootstrap method and the linear model with plateau.

\section{Hatheway method}

For the three spatial arrangements $(2 \mathrm{R}: 2 \mathrm{C}, 3 \mathrm{R}: 3 \mathrm{C}$, and $4 \mathrm{R}: 4 \mathrm{C}$ ), the relationship between plot size and Hatheway method variables was clearly observed. It has been found that a reduction of the convenient size of the experimental plot is provided by the increase in the number of repetitions, increase in the number of treatments, increase in the difference to be detected between treatments, and by the reduction of the coefficient of variation.

Among these factors, the coefficient of variation was the one that most influenced the size of the plot, since increases in the magnitudes of said factor provided significant increases in plot size, reaching impractical values in some combinations of number of replications, number of treatments, and difference between treatments. Similar results were observed by Viana et al. (2003), Muniz et al. (2009), Oliveira et al. (2011), and Sousa et al. (2016). This fact is very important because it confirms that the coefficient of variation is the measure most used as indicative of the quality of the experiments (Le Clerg 1967, Gomez and Gomez 1984, Petersen 1994).

Moreover, the increase in the accuracy and precision required, as a reflection of the reduction in the difference to be detected between treatments, also gives rise to dramatic increases in the plot size. On the other hand, increases in the number of repetitions and treatments are the least influential, the latter having less weight than the former.

Thus, the size of the plot decreased with less experimental precision (lower coefficient of variation) and a smaller difference between treatments, maintaining a constant number of treatments and repetitions, justifying the use of fewer basic units in each spatial arrangement under these conditions. The adoption of smaller plots reduces the costs of research on intercropped crops in relation to area, inputs, labor, and time (Henriques Neto et al. 2004).

When compared to the other methods studied herein, the Hatheway method agrees with the bootstrap resampling method, and with the sampling intensity with $10 \%$ error when using a $10 \%$ variation coefficient, difference between treatments of $10 \%$, four replicates and 10 treatments. In addition, the Hatheway values agree with the modified maximum curvature method, when using a coefficient of variation of $10 \%$, four replications, 10 treatments, and a difference between treatments of $30 \%$, a fact that may weaken the statistical validity of the estimates obtained. Similar results were obtained in melon for fruit weight, soluble solids, pulp firmness, and pulp thickness. 
YIELD AND COMPONENTS OF ARUGULA AND CARROT

Variations in plant distribution patterns in the spatial arrangements (also called planting settings) significantly affect the production of the component cultures of intercropping. The distribution of plants in the spatial arrangements is what determines the form of the available area to the individual plant (Lima et al. 2014). On the other hand, one of the factors that affects the yields of the component cultures in intercropping systems more is the proximity of these crops because this directly affects the degree of intra- and interspecific competition between them, so that this competition is greater the more closely arranged they are. Thus, low interspecific competition is essential so that cultures can express all their productive potential when intercropped (Schuster et al. 2013).

Higher yields of dry mass, green mass, and number of arugula leaves, and yields of dry mass of shoot and roots of carrot, obtained in the spatial arrangement $2 \mathrm{R}: 2 \mathrm{C}$, are due to less competition between the arugula and carrot plants, when compared to the competition in spatial arrangements 3R:3C and $4 \mathrm{R}: 4 \mathrm{C}$, with the best use of environmental resources by the crops. For commercial root yield of carrot, the highest values were obtained in the spatial arrangements $2 \mathrm{R}: 2 \mathrm{C}$ and 3R:3C, where the lower intra- and interspecific competitions were recorded, compared to the spatial arrangement $4 \mathrm{R}: 4 \mathrm{C}$, i.e., better use was made of the environmental resources in these two arrangements. The sum of the percentages of long and medium roots was higher in spatial arrangements 3R:3C (87.02\%) and 4R:4C (82.76\%), values which differ from those obtained by Bezerra Neto et al. (2003), who studied the intercropping of lettuce (Lactuca sativa L.) and carrot in the spatial arrangements 3R:3C and 4R:4C, obtaining the percentages $70.16 \%$ and $67.25 \%$, respectively, in these spatial arrangements.
The values of carrot aggressivity were positive, and the values of arugula aggressivity negative, indicating that the carrot is the dominant culture and arugula is the dominated culture in the intercropping (Lima et al. 2010). The relative crowding coefficient is an agronomic indicator of interspecific competitive relationships that are established in the intercropping system. Thus, the results obtained in different spatial arrangements were all greater than one, indicating the advantage of the intercropping system, with carrot producing more than the expected production. For the competitive ratio, the results obtained were around two in the different spatial arrangements. This competition index expresses the exact degree of competition between the species, by the number of times that the dominant species is more competitive than the dominated species (Eskandari and Ghanbari 2010). In the arrangement 2R:2C, the competitive ratio values of the cultures were similar, whereas in the arrangements $3 \mathrm{R}: 3 \mathrm{C}$ and $4 \mathrm{R}: 4 \mathrm{C}$, the competitive ratio of the carrot was about one and half times that of the arugula. This is due to the proximity of cultures in the spatial arrangement 2R:2C.

The values obtained for land equivalent ratio were greater than one, especially for the spatial arrangement 2R:2C (1:51). The land equivalent ratio measures the efficiency of the intercropping system in the use of environmental resources, compared to monocrops (Oseni 2010). Land equivalent ratio values larger than one in an intercropping system indicate that the intercropping was advantageous compared to single crops. Cecílio Filho et al. (2013) reported that the advantage of intercropping via land equivalent ratio comes from two different sources - the land factor (area occupied by each component culture) and biological/agronomic factor (arising from factor-tested treatments). In this research, the biological/agronomic factor was what gave the advantage to the intercroppings. 
The value of the real yield loss in the different spatial arrangements was positive, with the spatial arrangement 2R:2C (1.06) also standing out from the rest. It is important to note that the real yield loss values provide more accurate information concerning intra- and interspecific competition among species in the intercropping system (Dhima et al. 2007). Real yield loss values greater than one indicate that the intercropping system is advantageous in relation to the sole crop.

The intercropping advantage values in the spatial arrangements studied in this work were positive, with the value of the spatial arrangement 2R:2C (3.56) excelling that of spatial arrangements 3R:3C (1:13) and 4R:4C (0.14). The intercropping advantage is an indicator of the economic viability of the intercropping system (Banik et al. 2000). The higher the positive value of the intercropping advantage, the higher the economic advantage of the intercropping system.

\section{ECONOMIC INDICES}

The highest values of gross income, net income, modified monetary advantage, return rate, and profit margin were obtained from the spatial arrangement 2R:2C, being, respectively, $\mathrm{R} \$ 105,124.35$, $\mathrm{R} \$ 86,663.84$, $\mathrm{R} \$ 29,414.67,4: 51$, and $82.15 \%$. Net income is an indicator that expresses the economic value of an intercropping system better than gross income because the production costs are deducted in that (Oliveira et al. 2004); however, the modified monetary advantage translates the biological productivity of the intercropping, confirmed by the land equivalent ratio, in terms of economic advantage, indicating that the most profitable value of the intercropping system was obtained in the arrangement $2 \mathrm{R}: 2 \mathrm{C}$. Both the return rate $(4: 51)$, and the profit margin $(82.15 \%)$ also expressed the superiority of the spatial arrangement $2 \mathrm{R}: 2 \mathrm{C}$, indicating that, for every $\mathrm{R} \$ 1.00$ invested in the intercropping of arugula with carrot in the arrangement $2 \mathrm{R}: 2 \mathrm{C}$, there was a return of $\mathrm{R} \$ 4.51$ or, in terms of economic advantage, a profitability of about $82 \%$. These results express a biological advantage in monetary terms, indicating that the agronomic superiority obtained in the spatial arrangement 2R:2C was translated into economic advantage.

Finally, it is also important to mention that all economic indices obtained in the spatial arrangements 3R:3C and 4R:4C were high, and useful to express the agronomic/biological performance of the tested intercropping systems, thus placing at the disposal of the small producer other options for profit or monetary advantage with the practice of the intercropping of arugula and carrot.

\section{CONCLUSIONS}

Estimates of optimal sizes of experimental plots in intercropping systems given by the methods of bootstrap resampling and sampling intensity $(10 \%)$ were of four, four and three basic units, respectively, for the spatial arrangements $2 \mathrm{R}: 2 \mathrm{C}$, 3R:3C, and 4R:4C between rows of arugula (R) intercropped with carrot $(\mathrm{C})$. Using the Hatheway method, all spatial arrangements were of four basic units. The best bio-agroeconomic performance of carrot intercropped with arugula in bi-cultivation was obtained in the spatial arrangement 2R:2C.

\section{ACKNOWLEDGMENTS}

Special thanks are due to the Coordenação de Aperfeiçoamento de Pessoal de Nível Superior (CAPES) for their financial support of this work, and to the Plant Science research group of the Universidade Federal Rural do Semi-Árido, Instituto Federal do Ceará - Campus Iguatu, and the Instituto Federal da Paraíba - Campus Sousa, which develop technologies for growing vegetable crops on family farms. 


\section{REFERENCES}

ALMEIDA AES, BEZERRA NETO F, COSTA LR, SILVA ML, LIMA JSS AND BARROS JÚNIOR AP. 2015. Eficiência agronômica do consórcio alface-rúcula fertilizado com flor-de-seda. Rev Caatinga 28: 79-85.

AUGUSTYNCZIK ALD, MACHADO SA, FIGUEIREDO FILHO A AND NETTO SP. 2013. Avaliação do tamanho de parcelas e de intensidade de amostragem em inventários florestais. Sci For 41: 361-368.

BAKKER OA. 1988. Tamanho e forma ótimos de parcelas em delineamentos experimentais. Escola Superior de Agricultura Luís de Queiróz. (Dissertação de Mestrado em Estatística e Experimentação Agronômica), 142 p. (Unpublished).

BANIK P, SASMAL T, GHOSAL PK AND BAGCHI DK. 2000. Evaluation of mustard (Brassica campestris var. Toria) and legume intercropping under $1: 1$ and 2:1 row-replacement series system. J Agron Crop Sci 185: 9-14.

BARBIN D. 1993. Componentes de variância: teoria e aplicações. $2^{\mathrm{a}}$ ed., Piracicaba, FEALQ, 120 p.

BARROS JÚNIOR AP, BEZERRA NETO F, SILVA EO, NEGREIROS MZ, OLIVEIRA EQ, SILVEIRA LM, LIMA JSS AND FREITAS KKC. 2005. Qualidade de raízes de cenoura em sistemas consorciados com alface sob diferentes densidades populacionais. Hortic Bras 23: 290-293.

BEZERRA NETO F, ANDRADE FV, NEGREIROS MZ AND SANTOS JÚNIOR JS. 2003. Desempenho agroeconômico do consórcio cenoura $\mathrm{x}$ alface lisa em dois sistemas de cultivo em faixa. Hortic Bras 21: 635-641.

BEZERRA NETO F, GOMES EG AND OLIVEIRA AM. 2007. Produtividade biológica em sistemas consorciados de cenoura e alface avaliada através de indicadores agroeconômicos e métodos multicritério. Hortic Bras 25: 193-198.

BHATTI IH, AHMAD R, JABBAR A, NAZIR MS AND MAHMOOD T. 2006. Competitive behaviour of component crops in different sesame-legume intercropping systems. Int J Agric Biol 8: 165-167.

BRITO MCM, FARIA GA, MORAIS AR, SOUZA EM AND DANTAS JLL. 2012. Estimação do tamanho ótimo de parcela via regressão antitônica. Rev Bras Biom 30: 353-366.

CARGNELUTTI FILHO A, LOPES SH, BRUM B, TOEBE M, SILVEIRA TR AND CASAROTTO G. 2012. Tamanho de amostra para a estimação do coeficiente de correlação linear de Pearson entre caracteres de mamoneira. Semin-Cienc Agrar 33: 953-962.

CARGNELUTTI FILHO A, TOEBE M, BURIN C, CASARROTO G AND LÚCIO AD. 2011. Métodos de estimativa do tamanho ótimo de parcelas experimentais de híbridos de milho simples, triplo e duplo. Cienc Rural 41: $1509-1511$.

CECÍLIO FILHO AB, BEZERRA NETO F, REZENDE BLA, GRANGEIRO LC AND LIMA JSS. 2013. Indices of competition and bio-agroeconomic efficiency of lettuce and tomato intercrops in greenhouses. Aust J Crop Sci 7: 809-819.

CHAVES LJ. 1985. Tamanho da parcela para seleção de progênies de milho (Zea mays L.). Escola Superior de Agricultura Luiz de Queiroz. (Tese de Doutorado em Estatística e Experimentação Agronômica), 148 p.

COCCO C, BOLIGON AA, ANDRÍOLO JL, OLIVEIRA CS AND LORENTZ LH. 2009. Tamanho e forma de parcela em experimentos com morangueiro cultivado em solo ou em hidroponia. Pesqui Agropecu Bras 44: 681-686.

COCHRAN WG. 1977. Sampling Techniques. $3^{\text {rd }}$ ed., New York, J Willey \& Sons, Inc., 448 p.

COELHO FC, FREITAS SP AND RODRIGUES R. 2000. Manejo de plantas daninhas e sistema de consórcio na cultura do quiabeiro: produtividade e qualidade de frutos. In: Congresso Brasileiro de Olericultura, 40, 2000, São Pedro, Resumos..., Brasília: SOB/FCAV-UNESP 18(2): 587-588.

DHIMA KV, LITHOURGIDIS AS, VASILAKOGLOU IB AND DORDAS CA. 2007. Competition indices of common vetch and cereal intercrops in two seeding ratio. Field Crop Res 100: 249-256.

EFRON B AND TIBSHIRANI RJ. 1993. An introduction to the bootstrap. New York, Chapman \& Hall, 436 p.

EMBRAPA. 2006. Sistema Brasileiro de Classificação de Solos. $2^{\text {a }}$ ed., Embrapa, Rio de Janeiro, 306 p.

ESKANDARI H AND GHANBARI A. 2010. Environmental resource consumption in wheat (Triticum aestivum) and bean (Vicia faba) intercropping: comparison of nutrient uptake and light interception. Not Sci Biolog 2: 100-103.

ESPINOSA MM, SANDANIELO VLM AND LOUZADA NETO F. 2006. Método de bootstrap para o estudo de dados de fadiga dos materiais. Rev Mat Estat 24: 37-50.

FEIJÓ S, STORCK L, LÚCIO AD AND LOPES SJ. 2006. Heterogeneidade do solo e de tamanho de amostra antes e após cultivos com abobrinha italiana em estufa plástica. Cienc Rural 36: 1744-1748.

FREITAS KKC, BEZERRA NETO F, GRANGEIRO LC, LIMA JSS, MOURA KHS AND BARROS JÚNIOR AP. 2009. Desempenho agronômico de rúcula sob diferentes espaçamentos e épocas de plantio. Rev Cienc Agron 40: 449-454.

GOMEZ KA AND GOMEZ AA. 1984. Statistical procedures for agricultural research. $2^{\text {nd }}$ ed., New York, J Wiley, $680 \mathrm{p}$.

HERNÁNDEZ MAS, CONTRERAS AM, VERDUZCO CV, CASTELLANOS JS, HERNÁNDEZ CS AND ROJAS MCJ. 2006. Determinación del tamaño adecuado de parcela experimental en calabaza pipiana (Cucurbita argyrosperma 
Huber var. sternosperma). Rev Fitotec Mex 29: 339-348.

HENRIQUES NETO D, SEDIYAMA T, SOUZA MA, CECON PR, YAMANAKA $\mathrm{CH}$, SEDIYAMA MAN AND VIANA AES. 2004. Tamanho de parcelas em experimentos com trigo irrigado sob plantio direto e convencional. Pesqui Agropecu Bras 39: 517-524.

HENRIQUES NETO D, SEDIYAMA T, SOUZA MA, LEITE LFC AND BLANCO FF. 2009. Tamanho de parcela para avaliação da produção em trigo irrigado, sob dois sistemas de plantio. Rev Cienc Agron 40: 86-93.

LANA MM AND VIEIRA JV. 2000. Fisiologia e manuseio pós-colheita de cenoura. Brasília, Embrapa-Hortaliças, $16 \mathrm{p}$.

LE CLERG E. L. 1967. Significance of experimental design in plant breeding. In: Frey KJ (Ed), Plant Breeding Symphosium. Ames, Iowa State University, p. 243-313.

LEITE MSO. 2007. Tamanho da amostra para seleção de famílias de cana-de-açúcar. Universidade Federal de Viçosa. (Dissertação de Mestrado em Genética e Melhoramento de plantas), 51 p. (Unpublished).

LIMA JF, PEIXOTO CP, LEDO CAS AND FARIA GA. 2007. Tamanho ótimo de parcela para experimentos com plantas de mamoeiro em casa de vegetação. Cienc Agrotec 31: 1411-1415.

LIMA JSS, BEZERRA NETO F, NEGREIROS MZ, RIBEIRO MCC AND BARROS JÚNIOR AP. 2010. Productive performance of carrot and rocket cultivars in strip-intercropping system and sole crops. Agrociencia 44: 561-574.

LIMA VIA, LIMA SSL, BEZERRA NETO F, SANTOS EC, RODRIGUES GSO AND PAULA VFS. 2014. Viabilidade agroeconômica do cultivo consorciado de coentro, alface e rúcula sob diferentes arranjos espaciais. Encicl Biosfera 10: 3060-3065.

LÚCIO AD, CARPES RH, STORCK L, ZANARDO B, TOEBE M, PUHL OJ AND SANTOS JRA. 2010. Agrupamento de colheitas de tomate estimativas de tamanho de parcela em cultivo protegido. Hortic Bras 28: 190-196.

LÚCIO AD, MELLO RM, STORCK L, CARPES RH, BOLIGON AA AND ZANARDO B. 2004. Estimativa de parâmetros para o planejamento de experimentos com cultura do pimentão em área restrita. Hortic Bras 22: 766-770.

MEIER VD AND LESSMAN KJ. 1971. Estimation of optimum field plot shape and size for testing yield in Crambe abyssinica Hochst. Crop Sci 11: 648-650.

MELLO RM, LÚCIO AD, STORCK L, LORENTZ LH, CARPES RH AND BOLIGON AA. 2004. Size and form of plots for the culture of the italian pumpkin in plastic greenhouse. Sci Agr 61: 457-461.

MOURA KHS. 2008. Determinação do tamanho da amostra para determinação de híbridos de melão amarelo. Universidade Federal Rural do Semi-Árido. (Dissertação de Mestrado em Agronomia: Fitotecnia), 56 p. (Unpublished).

MUNIZ JA, AQUINO LH, SIMPLÍCIO E AND SOARES AR. 2009. Estudo do tamanho de parcelas experimentais em povoamentos de Eucalyptus grandis Hill, usando parcelas lineares. Cienc Agrotec 33: 1002-1010.

NEPPL GP, WEHNER TC AND SCHULTHEIS JR. 2003. Interaction of border and center rows of multiple row plots in watermelon yield trials. Euphytica 131: 225-234.

NUNES GHS, TORQUATO JE, SALES JÚNIOR R, FERREIRA HÁ AND BEZERRA NETO F. 2006. Tamanho amostral para estimar o teor de sólidos solúveis totais em talhões de melão amarelo. Rev Caatinga 19: 117-122.

OLIVEIRA EQ, BEZERRA NETO F, NEGREIROS MZ AND BARROS JÚNIOR AP. 2004. Desempenho agroeconômico do bicultivo de alface em sistema solteiro e consorciado com cenoura. Hortic Bras 22: 712-717.

OLIVEIRA GMV, MELLO JM, LIMA RR, SCOLFORO JRS AND OLIVEIRA AD. 2011. Tamanho e forma de parcelas experimentais para Eremanthus erythropappus. Rev Cerne 17: 327-338.

OSENI TO. 2010. Evaluation of sorghum-cowpea intercrop productivity in savanna agro-ecology using competition indices. J Agr Sci 2: 230-234.

PARANAÍBA PF, FERREIRA DF AND DE MORAIS AR. 2009a. Tamanho ótimo de parcelas experimentais: proposição de métodos de estimação. Rev Bras Biom 27: 255-268.

PARANAÍBA PF, MORAIS AR AND FERREIRA DF. $2009 \mathrm{~b}$. Tamanho ótimo de parcelas experimentais: Comparação de métodos em experimentos de trigo e mandioca. Rev Bras Biom 27: 81-90.

PEIXOTO APB, FARIA GA AND MORAIS AR. 2011. Modelos de regressão com platô na estimativa do tamanho de parcelas em experimento de conservação in vitro maracujazeiro. Cienc Rural 41: 1907-1913.

PETERSEN RG. 1994. Agricultural field experiments: design and analysis. New York, M. Dekker, 409 p.

SANTOS D, HAESBAERT FM, LÚCIO AD, STORCK L AND CARGNELUTTI FILHO A. 2012. Tamanho ótimo de parcela para a cultura do feijão-vagem. Rev Cienc Agron 43: 119-128.

SCHUSTER MZ, SZYMCZAK LS, LUSTOSA SBC, PELISSARI A, MORAES A AND FRANCISCO R. 2013. Interferência de plantas daninhas no estabelecimento do trevo branco como cultura forrageira. Cienc Rural 43: 2148-2153.

SILVA AFA, SOUZA EGF, SANTOS MG, BARROS JÚNIOR AP, BEZERRA NETO F AND SILVEIRA LM. 2015. Rentabilidade do rabanete adubado com flor-de-seda em duas épocas de cultivo no semiárido de Pernambuco. Rev 
Cienc Agrar 58: 198-207.

SILVA JR. 2009. Tamanho de parcela e efeito de bordadura em experimentos com meloeiro. Universidade Federal Rural do Semi-Árido. (Tese de Doutorado em Fitotecnia), 142 p.

SILVA RL, XAVIER A, LEITE HG AND PIRES IE. 2003. Determinação do tamanho ótimo da parcela experimental pelos métodos da máxima curvatura modificado, do coeficiente de correlação intraclasse e da análise visual em testes clonais de eucalipto. Rev Árvore 27: 669-676.

SOUSA RP, SILVA PSL AND ASSIS JP. 2016. Tamanho e forma de parcelas para experimentos com girassol. Rev Cienc Agron md 47: 683-690.

SOUSA RP, SILVA PSL, ASSIS JP, SILVA J, OLIVEIRA VR AND OLIVEIRA AMP. 2015. Tamanho ótimo de parcela para avaliação do rendimento de grãos do girassol. Rev Bras Eng Agríc Ambiental 19: 21-26.
TOEBE M, CARGNELUTTI FILHO A, BURIN C, CASAROTO G AND HAESBAERT FM. 2014. Tamanho de amostra para estimação da média e do coeficiente de variação em milho. Pesqui Agropecu Bras 49: 860-871.

VIANA AES, SEDIYAMA T, LOPES SC, CECON PR AND SILVA AA. 2003. Estudos sobre tamanho de parcela em experimentos com mandioca (Manihot esculenta Crantz). Acta Sci Agron 25: 281-289.

VIEIRA JV AND SILVA GO. 2008. Tamanho mínimo de parcela para avaliação de caracteres em raiz de cenoura. Bragantia 67: 1047-1052.

WILLIAMS AC AND MCCARTHY BC. 2001. A new index of interspecific competition for replacement and additive designs. Ecol Res 16: 29-40.

XIE C AND MOSJIDIS JA. 1997. Influence of sampling on precision of heritability and expected selection in red clover. Plant Breeding 116: 83-88. 